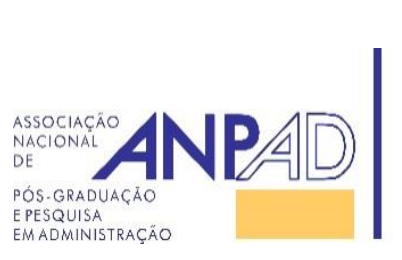

Available online at http://www.anpad.org.br/bar

BAR, Rio de Janeiro, v. 14, n. 3, art. 6, e170013, 2017

\title{
Career Profiles of Generation Y and Their Potential Influencers
}

Received 4 February 2017; received in revised form 3 June 2017; accepted 26 September 2017; first published online 24 October 2017.

Editor's note. Jair Nascimento dos Santos served as Action Editor for this article. 


\begin{abstract}
This study aims to identify the predominant career profiles among Generation $Y$ in Brazil and investigate the influence of demographic and professional characteristics in these profiles. Career profiles are defined as combinations of the presence of Boundaryless and Protean career attitudes. This study is descriptive, the sample is non-probabilistic and intentional and consists of 2,376 people. Cluster Analysis and Chi-square tests were used. The results show that people from Generation Y have a high presence of attitudes related to new careers and that these new careers are associated with high education and high income, mainly the Boundaryless career. However, there is a small portion of the sample that doesn't present new career attitudes, indicating that this is just a movement and cannot be considered a reality for all studied subjects.
\end{abstract}

Key words: generations; career; boundaryless career; protean career; career profile. 


\section{Introduction}

New career theories are recent and several studies about them are being conducted, nevertheless, there is still need for empirical verification of concepts (Clarke, 2013; Rodrigues \& Guest, 2010). In order to reduce this gap, it has been recommended that researchers develop more empirical studies about new careers and the impact of potential influencers, such as, age, gender, scholarship, etc. (Briscoe, Hall, \& DeMuth, 2006; Segers, Inceoglu, Vloeberghs, Bartram, \& Henderickx, 2008; R. C. da Silva, Dias, Silva, Krakauer, \& Marinho, 2012).

One of these potential influencers is the demographic change that is happening in Brazil related to the larger number of young professionals joining the workforce and the large number of people advancing to retirement age (Instituto Brasileiro de Geografia e Estatística [IBGE], n.d.).

These young professionals are getting attention from media and organizations. Born after 1981, they are named Generation Y (Amaral, 2004). Generation Y has the main characteristic of being born in a digital environment (with the frequent presence of computers, cell phones, internet access, etc.) and that is why Tapscott (2010) calls them the Net Generation. Considering generational differences, these individuals have different expectations and attitudes regarding their careers compared to other Generations (Lyons, Schweitzer, \& Ng, 2015).

Taking into consideration the new careers theories and their need for empirical verification and also the economic importance of the large number of professionals from Generation $\mathrm{Y}$ joining the Brazilian workforce, the current study objective is to identify the career profiles of Generation Y and investigate how demographics and professional characteristics affect these profiles. Career profiles are based upon combinations of the Boundaryless and Protean career attitudes (Briscoe \& Hall, 2006).

Understanding the presence of new career attitudes allows organizations to develop more effective career management and generational inclusion practices. It is also relevant to career actors, because it supports different ways for them to develop careers aligned with their values and interests during an important moment of their professional identity formation.

\section{Literature Review}

During the last 25 years, the most commonly used approaches to reflect on new careers were the Boundaryless and Protean careers (Baruch, Szucs, \& Gunz, 2014). After detailing these concepts, this section will also go deeper into the subject of Generations, focusing mainly on Generation Y as the main target of this paper.

\section{Boundaryless career}

Arthur and Rousseau (1996) define the Boundaryless career as the opposite of the organizational career. The name Boundaryless is used because the limits of the organizational career are broken, such as hierarchical structures and career advancement principles.

The career actor is shaped by economic forces but also influences those forces, therefore, he/she is the product and the producer of the work environment in which he/she participates, reversing the traditional career logic that positions the career actor as passive towards environmental changes (Arthur, 1994; Arthur, Inkson, \& Pringle, 1999).

The Boundaryless career emphasizes the numerous possibilities that a career presents - it isn't related to a single organization and isn't represented in an orderly and vertical sequence. It is supported by networks from outside the organization and acknowledges that family and personal relationships play 
an important role. According to this construct, the career must be interpreted in a subjective way, according to the career actor perspective about his/her own career (Arthur, 1994, 2014; Briscoe \& Hall, 2006).

Sullivan and Arthur (2006) describe the Boundaryless career in two dimensions: the physical and psychological. The career actor demonstrates physical mobility when he/she moves between employers and demonstrates psychological mobility when he/she builds relationships outside the boundaries of a single employer. Those two dimensions are represented as a continuum. It is important to clarify that the Boundaryless career isn't based only on physical mobility and that someone who has high tenure in a single organization can still have a boundaryless mindset.

\section{Protean career}

The Protean career is characterized by frequent change and self-invention, autonomy and selfmanagement, guided by individual needs instead of organizational needs. That is why the name Protean was chosen, referring to the Greek god called Proteus that changes his own shape according to his will (Hall, 2002).

The Protean career is managed by the career actor according to his/her own needs, values and the search for psychological success, instead of an external definition of success. For the career actor to manage his/her career requires flexibility and adaptability, but also to be driven by a strong sense of identity and self-awareness that will work as an internal compass to make career decisions (Hall, 2002).

Considering the Protean approach, the employer has the role of offering opportunities, flexibility and resources to allow the employee to develop self-awareness and adaptability and be in the command of his/her own career. The role of the employee is to give performance and discretionary effort in return (Hall, 2002).

Big cities, such as São Paulo, enable Protean career development because they have facilities that strengthen autonomy, such as access to education, a large number of employers, high financial investments, health care system, etc. (Ribeiro, Trevisan, \& Guedes, 2009).

Briscoe and Hall (2006) define two main dimensions of the Protean career: the self-direction and the values driven. The first grants the ability to adapt in terms of performance and learning demands, and the second allows a clear direction and career success measurement, replacing external motivational drivers, such as job title and salary.

\section{Boundaryless and Protean career attitudes scales and career profiles}

In order to support more empirical studies about new careers, Briscoe, Hall and DeMuth (2006) proposed scales to measure Boundaryless and Protean career attitudes. The authors developed and validated a model with four scales, two for each construct and with 7 questions each. The model is described in Table 1: 
Table 1

\section{Boundaryless and Protean Career Attitudes Scale}

\section{Boundaryless Career}

Psychological mobility: general attitude of working beyond organizational boundaries, presenting interest in interacting with people from outside the organization and having constant new work and learning experiences.

Physical mobility: interest in moving between different employers.

\section{Protean Career}

Self-directed: the career actor drives his/her own career and builds development opportunities and the ability to adapt in terms of work and performance demands.

Note. Source: adapted by the authors based on Briscoe, J. P., \& Hall, D. T. (2006). The interplay of boundaryless and protean careers: Combinations and implications (p. 5). Journal of Vocational Behaviour, 69(1), 4-18. https://doi.org/10.1016/j.jvb.2005.09.002

After building the scales, Briscoe and Hall (2006) proposed eight career profiles using combinations of the career dimensions. Considering the four career scales, it is possible to build sixteen career profiles, but only eight were suggested, based on the practical experience of the authors. The most probable profiles are described in Table 2.

Table 2

Career Profiles

\begin{tabular}{ccccc}
\hline Career Profiles & $\begin{array}{c}\text { Protean: Self- } \\
\text { directed }\end{array}$ & $\begin{array}{c}\text { Protean: Values } \\
\text { Driven }\end{array}$ & $\begin{array}{c}\text { Boundaryless: } \\
\text { Psychological } \\
\text { Mobility }\end{array}$ & $\begin{array}{c}\text { Boundaryless: } \\
\text { Physical } \\
\text { Mobility }\end{array}$ \\
\hline Lost & Low & Low & Low & Low \\
\hline Fortressed & Low & High & Low & Low \\
\hline Wanderer & Low & Low & Low & High \\
\hline Idealist & Low & High & High & Low \\
\hline Organization man/woman & High & Low & High & Low \\
\hline Solid Citizen & High & High & High & Low \\
\hline Hired gun & High & Low & High & High \\
\hline Protean career architect & High & High & High & High \\
\hline
\end{tabular}

Note. Source: adapted by the authors based on Briscoe, J. P., \& Hall, D. T. (2006). The interplay of boundaryless and protean careers: Combinations and implications (p. 8). Journal of Vocational Behaviour, 69(1), 4-18. https://doi.org/10.1016/j.jvb.2005.09.002

Briscoe and Hall (2006) described the characteristics of each profile. The Lost, for example, represents the traditional career profile. The career actors that have this profile lack emphasis on their personal values, that could drive them, and lack a boundaryless mindset that could provide them with more possibilities. Therefore, they are restricted to few options in which they have limited control. These are the individuals that need strong adaptation to the new economy. On the other hand, the Protean career architect is the most modern profile. The career actors with this profile are physically and psychologically boundaryless and actively manage their own careers based on their personal values in a journey to define career success.

The identification of career profiles allows the exploration of personal challenges that a career actor can face to keep their status-quo. They are also a useful tool for organizations, support groups, career counselors and mentors that are interested in supporting career development. Understanding the 
strengths of a career profile allows the careful development of powerful combinations of career competencies (Briscoe \& Hall, 2006).

\section{Influence of demographic and professional characteristics on career attitudes and profiles}

Briscoe, Hall and Mayrhofer (2012) alert that the current research about careers is based on the universalist paradigm. They therefore assume that individuals and organizations are identical everywhere and that there is an ideal way to manage them. These authors argue that organizations and individuals are socially impacted by the external environment and culture that they live in, which makes them adapt to current structures and engage in behaviors to cope with their context. Considering this argument, they propose a contextual approach to studying careers, putting culture as a critical element of differentiation of the way that a career is perceived and managed. The current study uses this contextual approach and aims to understand how demographics and professional elements impact career attitudes.

One of the studies that also uses this approach is the one made by Segers, Inceoglu, Vloeberghs, Bartram and Henderickx (2008). The researchers adapted the items of a motivation scale to the four career attitudes dimensions proposed by Briscoe et al. (2006) and evaluated the relationship between the career attitudes of 13,000 European individuals and their demographic characteristics. The main findings were:

- Gender: women presented higher psychological mobility and men presented higher physical mobility. These findings are associated with the career disruptions that happen to women due to child birth and due to social expectations towards men related to family support obligations.

- Age: the younger respondents presented higher psychological mobility, because of their interest in building relationship and networks, and presented lower values orientation. People joining the workforce go through a trial and error stage looking for ways to manage their careers. The desire to move physically decreases with the age.

- Education: individuals with higher educational levels present more self-direction, physical and psychological mobility and less values orientation.

- Professional experience: individuals with higher professional experience present higher selfdirection, physical and psychological mobility.

Besides the findings mentioned above, Segers et al. (2008) study identified four clusters, three of them described by Briscoe and Hall (2006): Lost, Hired Gun, and Protean career architect, and a fourth one not mentioned before presenting low scores on the Protean career dimensions and high scores on the Boundaryless career dimensions. This last cluster was named as Curious. They also identified the demographic profile predominant in each of the four clusters. These results are presented in Table 3 . 
Table 3

Relationship between Demographic Characteristics and Career Profiles

\begin{tabular}{lcccc}
\hline Career Profile & Gender & Age & Education & Work Experience \\
\hline Lost & Predominantly male & $\begin{array}{c}\text { More than 30. Most } \\
\text { part between } 40 \\
\text { and 50 }\end{array}$ & Up to High School & More than 10 years \\
\hline Curious & Predominantly female & Less than 30 & Up to High School & From 0 to 5 years \\
\hline Hired Gun & Predominantly male & Less than 40 & College or above & From 3 to 10 years \\
\hline $\begin{array}{l}\text { Protean Career } \\
\text { Architect }\end{array}$ & Predominantly female & Between 30 and 50 & College or above & $\begin{array}{c}\text { More than 5 years; } \\
\text { managerial experience }\end{array}$ \\
\hline
\end{tabular}

Note. Source: adapted by the authors based on Segers, J., Inceoglu, I., Vloeberghs, D., Bartram, D., \& Henderickx, E. (2008). Protean and boundaryless careers: A study on potential motivators (p. 224). Journal of Vocational Behavior, 73(2), 212-230. https://doi.org/10.1016/j.jvb.2008.05.001

J. de A. Silva (2009) studied the relationship between career and potential influencers in Brazil and found a positive association between psychological mobility and work experience and between physical mobility and age.

Many Brazilians avoid planning their careers. People tend to guide their career by external appeals, such as compensation, prestige, etc., more than personal preferences. In addition to this, people face their career as the process of identifying opportunities at their companies or in the marketplace. This posture leads to a movement based on external conditions, in which the current and accessible possibilities play a key role in the decisions taken (Dutra, 2010).

This paragraph concludes the conceptual background around careers. The next section will explore the theme Generations, summarizing the main theoretical aspects relevant to this study.

\section{Generations}

The most influent concept of Generations indicated by the current literature (Dencker, Joshi, \& Martocchio, 2007; Edmunds \& Turner, 2005; Parry \& Urwin, 2011) is Mannheim and Yncera's (1993). According to Mannheim and Yncera (1993), a Generation is part of the historical process that people of the same age and social class share during their youth. The birth date is an important driver, but doesn't define the Generation. There are two critical elements to constitute a Generation: the presence of events that break the historical continuity and the life experience by this age group during their socializing process (teenage and beginning of adult life), predisposing them to certain experiences and ways of thinking.

In order to build an effective analysis of the generational effects, they must be separated from the age effects (resulting from the age and maturing stage of the individual) and also from the period effect (environment impacts) (Dencker et al., 2007). There is a methodological difficulty in separating these effects and to minimize this difficult, Parry and Urwin (2011) recommend longitudinal studies to define generational effects.

Nowadays people management practitioners present a great interest in Generations and their impacts on the workplace. Several books and media articles have being published during the past years based on the practical experience of the authors or general stereotypes (R. C. da Silva, Dutra, \& Veloso, 2014).

Most international academic papers about the subject are theoretical and they cite sociologists, such as Mannheim, Ryder, Schuman and Scott, and psychologists to establish the conceptual basis. International articles are deeper, in technical terms, than most national articles because they work on 
concepts instead of working on the characteristics of the Generations. International empirical articles use longitudinal analyses (Smola \& Sutton, 2002; Twenge \& Campbell, 2008; Twenge, Campbell, Hoffmann, \& Lance, 2010) or statistical techniques to separate the age effect in the model (Benson \& Brown, 2011), which puts them in a better position than the national studies regarding the recommended method to study Generations (Parry \& Urwin, 2011).

National academic studies about Generations and People Management have been published in the last years. The first studies compare Generations and identify similarities regarding career anchors (Gomes, Trevisan, Veloso, \& Silva, 2013; Tieppo, Gomes, Sala, \& Trevisan, 2011; Vasconcelos, Merhi, Lopes, \& Silva, 2009), organizational commitment (Nogueira, Lemos, \& Cavazotte, 2011; Vale, Lima, \& Queiroz, 2011), career management and expectations considering the perspective of the career actor (Cavazotte, Lemos, \& Viana, 2010; R. C. da Silva et al., 2012; Ribeiro et al., 2009; Sá, Lemos, \& Cavazotte, 2014; Veloso, Dutra, \& Nakata, 2008; Veloso, Silva, \& Dutra, 2012) and career management considering the organizational perspective (R. C. da Silva, Dutra, \& Veloso, 2013, 2014). There is a greater interest in Generation Y, according to the number of articles published during the past few years.

Generations may vary according to national context, because individuals in different countries live different historical, social, economic and cultural backgrounds, which may interfere with the characteristics and limits between Generations (Briscoe, Hall, \& Mayrhofer, 2012; Parry \& Urwin, 2011). Nevertheless, the concepts of Generations have been incorporated into national research in the same way that they are used in international studies, without contextualization of the characteristics and historic moments that contribute to the Generational groups in Brazil (Rocha-de-Oliveira, Piccinini, \& Bitencourt, 2012).

It is common sense between Generations researchers that there are four generations coexisting in the current workplace: Veterans, Baby Boomers, Generation X and Generation Y (Briscoe et al., 2012; Veloso et al., 2008). Besides the few national studies, authors don't diverge significantly about the characteristics of each Generation (Veloso et al., 2008), but the finding of these researches usually aren't similar, nor conclusive (R. C. da Silva et al., 2014).

The current approach used to describe Generation Y can't fully explain the youth of a country where a college degree is a privilege and digital inclusion is a challenge (Rocha-de-Oliveira et al., 2012). Considering that Generations also represent class conditions, the premise that there is a single and uniform Generation Y in Brazil would mean to simplify the national reality, referring to the economic inequality and low educational level of the population.

Even though it isn't enough to describe the national reality, the profile defined in international studies provides a good starting point to understand the aspirations and behaviors of the youth of middle class Western civilizations (Sá et al., 2014). It is especially true for the Generation Y study, because globalization and modern communication means, such as the internet, amplified the participation of young people of different countries in similar happenings and experiences, placing them in the same generational position (Edmunds \& Turner, 2005; Tapscott, 2010).

Based on a practical experience of more than 10 years studying the subject in Brazil, Amaral (2004) proposed the year of 1981 as the start date for the Generation Y for the country. Its main historical milestone is related to technology and its consequences, such as connectivity, accessibility, globalization and social networks, developing this group's adaptability to a multi-tasking, agile and high-availability environment (Amaral, 2004; Dencker et al., 2007; Sá et al., 2014; Tapscott, 2010).

This Generation was raised in a stable political and economic environment, during and after the nineties, with the Brazilian economy opening to the world and inflation under control. The workplace was volatile and without guarantees because of frequent outsourcing, downsizing and reengineering movements. In this context, the key words were competitiveness and employability (Amaral, 2004; Gomes et al., 2013). Excessive care from parents was frequent, because many from Generation Y were the only child of parents that faced difficulties in their work life balance and many ended up living with their parents for a prolonged period (Amaral, 2004). 
Socialized in this context, the members of the Generation $\mathrm{Y}$ are described as individualist, flexible, controvert, and with desire for autonomy, work life balance and fast career growth (Amaral, 2004; Gomes et al., 2013; Tapscott, 2010; Tieppo et al., 2011; Twenge et al., 2010; Veloso et al., 2012).

At the workplace, they look for an environment that allows job satisfaction, learning and the development of a close network. They prefer to work with leaders that promote constant feedback and they are more inclined to higher job mobility (Briscoe et al., 2012; Cavazotte et al., 2010; Lyons et al., 2015; R. C. da Silva et al., 2013; Twenge \& Campbell, 2008; Twenge et al., 2010; Vasconcelos et al., 2009; Veloso et al., 2012).

In order to meet these needs, organizations are offering flexible work hours, locations and job descriptions. There are few evidences of adaptation in managerial practices specifically to attend the needs of different Generations (R. C. da Silva et al., 2013, 2014).

Considering the characteristics mentioned, it is supposed that Generation $\mathrm{Y}$ has attitudes compatible with new careers, such as career self-management, decisions based on their personal values, search for psychological success, and physical and psychological mobility. Some studies found a positive correlation between being part of the Generation Y and presenting new career attitudes (R. C. da Silva et al., 2012; Veloso et al., 2012) and other studies found opposite results, such as Tieppo, Gomes, Sala and Trevisan (2011) and Sá, Lemos and Cavazotte (2014). This last one, for example, indicates that a big part of the interviewees that were members of Generation Y presented expectations related to the traditional career models, such as: vertical career growth inside the company, training offered by the company, compelling compensation and job stability.

Besides the several methodological limitations, the Generations concept is useful because it casts light on the groups, the basis for their formation and consequences in work-related behaviors. Based on these valuable insights, many practitioners are developing people strategies and human resources practices based on this approach, understanding that generational issues are a key element to people management success. Academia is also interested in building a conceptual background on the subject. The practitioners and academic interest in the subject should be supported by empirical evidence and a national conceptualization should be built.

This research used Amaral's (2004) study as a basis to define the broad reality of Generation Y in Brazil, its characteristics and historic milestones. These milestones put them at a different generational position from previous generational groups. This study also considers the concept of Generations as described by Mannheim and Yncera (1993) and Rocha-de-Oliveira, Piccinini and Bitencourt (2012), by identifying and analyzing social variables of the sample studied and the impacts these variables have on career profiles. This is done while acknowledging that a single and uniform career profile of the Generation Y in Brazil could be limited and apart from the country reality.

Nevertheless, it is clear that individuality must be respected in all studies and several measures should be taken to avoid generalization that, when made without a strong conceptual basis, may hurt academic backgrounds and people management practices in organizations.

\section{Methodological Procedures}

The data collection instrument is based on the Boundaryless and Protean career attitudes scale developed by Briscoe et al. (2006), translated into Portuguese and validated in Brazil by Cordeiro and Albuquerque (2016).

The individuals were classified into career profiles using Cluster Analysis. Cluster Analysis is used to divide a sample of a population into a small number of groups based on the similarities, maximizing the homogeneity inside the groups at the same time that it maximizes the heterogeneity between groups (Hair, Black, Babin, Anderson, \& Tatham, 2009). 
According to Hair, Black, Babin, Anderson and Tatham (2009), since Cluster Analysis is a descriptive technique and may present different solutions, it is recommended to use theory to define the clusters. In this case, the basis was the conceptual career profiles defined by Briscoe and Hall (2006).

Considering that the study objective was to analyze the most prominent career profiles, the technique chosen for the Cluster Analysis was the K-means. The group divisions should respect the combinations of high and low career attitudes and this could only be done using concepts to define the seeds that would separate the groups.

The seeds were defined based on the combination of the 16 possible career profiles and the 8 profiles described as the most frequent. Briscoe and Hall (2006) specify the profiles in theoretical terms and the definitions of high or low presence of career attitudes aren't quantitatively defined. For this research, absolute values were used to define the seeds: -0.5 to represent low presence of career attitude and +0.5 to represent high presence of career attitude.

Cluster Analysis generated centroids for each group and each dimension. Groups with centroids below zero were considered as groups with low presence of the career attitude. On the other hand, groups with centroids above zero were considered as groups with high presence of the career attitude. Centroids close to zero had their significance tested by the Mann-Whitney test.

The influence of demographic and professional characteristics were investigated using the Chisquare test. The variables tested were defined based on articles that identified characteristics that could impact career profiles (R. C. da Silva et al., 2012; Scalabrin, 2008; Segers et al., 2008; Sullivan \& Arthur, 2006). Demographic (age, gender, education, marital status, number of children, city of residence, individual and family income) and professional variables (tenure, position, number of employers in the last 5 years) were tested.

The survey was administered with the support of NextView, a research company specialized in tendencies in people management and development. The link to access the survey was sent by email to 40,000 people and advertised on the ClickCarreira webpage. The data was collected using a SurveyMonkey electronic questionnaire between March $8^{\text {th }}$ and May $14^{\text {th }}, 2012^{(1)}$.

The initial database contained responses from 3,056 participants. Data cleaning eliminated respondents that answered the survey more than once (identified by the same email address), people that concentrate their responses in only one point of the scale, respondents that had less than one year of professional experience (because some questions were about past work experience) and respondents that were born before 1982 or after 1994. The final database had 2,376 answers and the results were analyzed using Excel and SPSS v. 20.

Respondents are mainly singles $(84 \%)$ without children $(93 \%)$ and with a small predominance of women $(57 \%)$, compared to the national reality that is formed by $51 \%$ women (IBGE, n.d.). The educational level of the sample is also higher than the national basis. $71 \%$ of the respondents have a college degree and $21 \%$ are post-graduates, compared to a national population of only $18 \%$ of national workers with college degrees or higher (Departamento Intersindical de Estatística e Estudos Socioeconômicos [DIEESE], 2011).

$59 \%$ of the respondents have individual income higher than the country average (IBGE, n.d.). The high family income indicates a sample composed of people belonging predominantly (75\%) to the A and B classes (Associação Brasileira de Empresas de Pesquisa [ABEP], 2012). 75\% of the sample have a family income above four minimum wages, compared to only $11 \%$ of the Brazilian population at the same family income level.

$50 \%$ of the respondents live in the state of São Paulo, $10 \%$ in Minas Gerais, $10 \%$ in Rio de Janeiro and the other $30 \%$ of the sample live in different Brazilian states. Compared to the national population distribution, with 22\% of residents in São Paulo, $10 \%$ in Minas Gerais and $8 \%$ in Rio de Janeiro, it is clear that the sample has a higher proportion of people living in São Paulo. Even so, the other regions 
were also represented, with $12 \%$ of the sample living in the South region, $9 \%$ in Northeast, $5 \%$ in the Midwest, and 2\% in the North.

The major part of the respondents are currently working (82.5\%) and present high job mobility, considering that the average tenure in the country, according to RAIS (DIEESE, 2011) is 3.9 years. This group presented an average tenure of 1.5 to 2.5 years. Half of the respondents hold jobs as analyst or assistant, $18 \%$ are interns and 15\% hold managerial positions (Director, Manager, Coordinator, Supervisor, and Consultant).

This study is descriptive and quantitative. The sample used in this study is non-probabilistic and intentional, due to the limited number of respondents $(2,376)$ compared to the national population of this age group (around 34 million) and also based on the characteristics of the sample described above. Even considering the limitations described, the diverse demographic characteristics and the large number of responses allowed for analysis, as presented in the next section.

\section{Analysis of Results}

\section{Cluster analysis: career profiles}

Initially the analysis was made using 16 seeds, representing all possible combinations of career attitudes. In this first analysis, the 8 profiles defined by Briscoe and Hall (2006) and other 8 profiles were found, indicating that other career profiles may be a possibility. These 16 clusters divided the sample a lot, generating many groups with a similar number of individuals.

The second analysis was built with only the 8 groups described as theoretically more probable. The results are described in Table 4.

Table 4

8-group Cluster Analysis

\begin{tabular}{|c|c|c|c|c|c|c|c|c|c|c|}
\hline \multirow[b]{2}{*}{$\begin{array}{c}\text { Grou } \\
\text { p }\end{array}$} & \multicolumn{4}{|c|}{ Centroids } & \multirow[b]{2}{*}{$\begin{array}{l}\text { Number of } \\
\text { individuals }\end{array}$} & \multicolumn{4}{|c|}{ Career Attitudes } & \multirow[b]{2}{*}{$\begin{array}{l}\text { Career } \\
\text { Profile }\end{array}$} \\
\hline & 岂 & 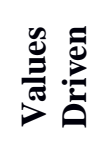 & 黄 & 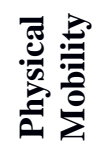 & & 窇 & 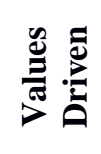 & 总 & 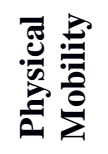 & \\
\hline 1 & -2.18 & -0.73 & -1.54 & -0.90 & $88(4 \%)$ & Low & Low & Low & Low & Lost \\
\hline 2 & 0.68 & 0.38 & -1.53 & $0.05^{*}$ & $283(12 \%)$ & High & High & Low & Neutral & Not defined \\
\hline 3 & -0.58 & 0.33 & -0.65 & 0.49 & $312(13 \%)$ & Low & High & Low & High & Not defined \\
\hline 4 & -1.32 & $0.07 *$ & 0.78 & 0.35 & $302(13 \%)$ & Low & Neutral & High & High & Not defined \\
\hline 5 & 0.31 & -0.96 & 0.31 & -1.12 & $254(11 \%)$ & High & Low & High & Low & $\begin{array}{l}\text { Organization } \\
\text { man/woman }\end{array}$ \\
\hline 6 & 0.27 & 0.82 & 0.46 & -1.44 & $275(11 \%)$ & High & High & High & Low & Solid Citizen \\
\hline 7 & 0.41 & -1.36 & 0.14 & 0.58 & $324(13 \%)$ & High & Low & High & High & Hired Gun \\
\hline 8 & 0.54 & 0.54 & 0.53 & 0.56 & $538(23 \%)$ & High & High & High & High & $\begin{array}{l}\text { Protean } \\
\text { Career } \\
\text { Architect }\end{array}$ \\
\hline
\end{tabular}

Note. The symbol * indicates that the value is not significant to the reliability level of 5\% in Mann-Whitney test. 
Besides using the theoretical background to define the seeds, the 8-group analysis led to only 5 of the 8 groups conceptually defined. The profiles Wanderer, Fortressed and Idealist weren't found. Even so, the other groups had a less proportional division of the respondents, indicating a more judicious solution.

Other solutions with less than 8 groups were analyzed to check if the profiles indicated in the theory would be found. The 5-group analysis, for example, built using the seeds that indicated only the 5 profiles found in the 8-group solution, grouped the Lost profile with the Fortressed and the number of people in this new group quadrupled. The Organization man/woman wasn't found. Both results indicate that 5 is too small a number of groups, one that gathers individuals with different profiles, affecting the centroids of the resulting groups. The analysis using 6 and 7 groups generated similar results, meaning that they generated less groups described in the theory and with centroid values close to zero, showing that the clusters were grouping individuals with very different profiles.

In order to have a second confirmation of the best solution in terms of number of clusters, the Ward technique was used. This tool indicated the 5-groups as the ideal solution, based on the agglomeration index. Nevertheless, due to the problems described before, this solution doesn't apply to the purpose of this study (find different career profile groups) and offers a limited relationship with the theory. However, the solution indicated by the Ward technique contributed to the definition of the best number of groups by indicating that a small number of groups, close to 5, is preferable than a larger number, and also supporting that the 8-group solution is more appropriate than the 16-group solution.

Using the 8-group solution, each profile has very well defined centroids for each career dimension. Only two centroids are very close to neutrality: Physical Mobility in Group 2 and Values Driven in Group 4. The analysis of the statistical significance of these centroids by the Mann-Whitney technique indicates that they can't be considered high, even if a little bit higher than zero. Therefore, these centroids were considered as neutral for those profiles.

The most representative cluster of the 8-group solution is the Protean Career Architect representing $23 \%$ of the respondents. This profile has high presence of all career attitudes studied. In the sequence, three other groups have 13\% of the valid respondents: Hired Gun, Group 3 and Group 4. The three groups with the biggest proportion of high career attitudes clearly appear in the Cluster Analysis (Protean Career Architect, Hired Gun and Solid Citizen). The group of the Lost profile, that has low presence of the four career attitudes, is the smallest one, representing only $4 \%$ of the valid respondents.

Besides using the theory to define the clusters' seeds, the analysis found three profiles different from the ones described by Briscoe and Hall (2006). These three groups were classified as follow.

Group 2: present themselves as Protean career, but not as Boundaryless career actors. This can happen due to a lack of experience and knowledge that allows then to navigate different environments or due to the lack of qualification to do this movement (Sullivan \& Arthur, 2006). An interesting element of this profile is the physical mobility neutrality, meaning that these individuals are at the borderline of movement and inertia. Even if their movements are less frequent, the Protean orientation may make them happen if the career actor decides it is necessary to his/her professional development or to keep the alignment with his/her values. Due to these characteristics, this group was named as Stable Protean.

Group 3: is composed by individuals that have little self-management of their careers and look for jobs similar to previous ones to avoid adaptation efforts, but, on the other hand, they are valuesdriven and can easily move physically, if they think it is interesting or needed. Considering those characteristics, this group was named Oriented Traveler, traveler due to their physical mobility and oriented due to its value orientation. The word oriented can be also associated with direction, but without the control or management, since this profile also present low self-direction, probably holding other people, organizations or the marketplace accountable for it.

Group 4: is composed of Boundaryless individuals, but with low Protean orientation. Sullivan and Arthur (2006) indicate that people with high presence of Boundaryless career attitudes present many 
physical movements while changing their psychological orientation. For example, this includes people that change jobs and look for learning opportunities and challenges while attending their personal or family needs. They are very flexible and adaptable. Besides this, they are neutral regarding the values orientation, suggesting that some decisions are made based on personal values and others aren't. The decisions not driven by values may be driven by other people, such as employers, colleagues, family members, etc. This profile makes sense in a sample composed of young professionals that are building self-awareness regarding their personal values and may have their decisions influenced by objective success and third parties. The statistically significant demographic that emerges for this profile is related to a low or average individual income and lower job positions, such as assistants and analysts. Considering this description, this profile was named Seeker suggesting this continuous physical and psychological movement and the space that these individuals have to increase their self-awareness, identify the role of their values in their lives and acknowledge that they are responsible for their careers.

\section{Analysis of the influence of demographic and professional characteristics in career attitudes}

Table 5 summarizes the statistically significant associations between career attitudes and characteristics in the sample, presenting only the variables that have the biggest proportion of individuals with high scores in the respective career attitude.

Table 5

Significant Relationships between Career Attitudes and Demographic Characteristics

\begin{tabular}{|c|c|c|c|c|}
\hline & Self-Directed & Values Driven & $\begin{array}{l}\text { Psychological } \\
\text { Mobility }\end{array}$ & Physical Mobility \\
\hline Birth year & & & & 23 to 26 years old \\
\hline Gender & & & & women \\
\hline Education & & & $\begin{array}{l}\text { high educational } \\
\text { level }\end{array}$ & high educational level \\
\hline Marital Status & Singles & & & \\
\hline Individual Income & $\begin{array}{l}\text { high individual } \\
\text { income }\end{array}$ & & $\begin{array}{l}\text { high individual } \\
\text { income }\end{array}$ & $\begin{array}{l}\text { high individual } \\
\text { income }\end{array}$ \\
\hline Family Income & & & high family income & high family income \\
\hline $\begin{array}{l}\text { State/City of } \\
\text { Residence }\end{array}$ & & $\begin{array}{l}\text { São Paulo city } \\
\text { residents }\end{array}$ & & \\
\hline $\begin{array}{l}\text { Years of } \\
\text { Professional } \\
\text { Experience }\end{array}$ & & $\begin{array}{l}\text { few years of } \\
\text { experience }\end{array}$ & more experienced & \\
\hline Job title & top positions & & top positions & \\
\hline $\begin{array}{l}\text { Number of } \\
\text { employers at the last } \\
5 \text { years }\end{array}$ & & & & many employers \\
\hline
\end{tabular}

Analyzing Table 5, it is possible to conclude that self-direction is more frequent among singles, higher-income and higher-position individuals. The higher income and the fact that they are single reinforce the independence of the career actor and allow a more flexible self-management of their careers.

The values orientation is more frequent among individuals living in São Paulo city and with limited work experience. Big cities, such as São Paulo, were identified by Ribeiro, Trevisan and Guedes 
(2009) as enablers of the Protean career orientation due to its work conditions, access to education, healthcare, etc. The values orientation is also more frequent for people with less work experience. This result is aligned with Dutra's (2010) description of the little ownership that Brazilian career actors present. People building job experience can be moving to a position of lower values orientation due to the adaptation of this marketplace status-quo.

The psychological mobility is more frequent in individuals with higher educational level (Segers et al., 2008), higher individual and family income, more years of work experience (Briscoe et al., 2006; J. de A. Silva, 2009; Segers et al., 2008) and holding top positions. These attributes allow the career actor more freedom to search for development opportunities and explore relationships outside their current workplace and organizational boundaries, explaining the higher psychological mobility.

The physical mobility is more frequent for 23 to 26 years old individuals, women, higher individual and family income holders and people that had a bigger number of different employers at the last 5 years, demonstrating alignment between physical mobility attitude and real job mobility. Segers et al. (2008) and J. de A. Silva (2009) noticed an inverse relation between age and physical mobility. The current study found similar results, since individuals older than 26 presented lower physical mobility.

Analyzing the association between physical mobility and gender, it is noticeable that women present higher physical mobility attitude than men. Segers et al. (2008) found higher physical mobility among men and explained this finding due to the career discontinuity related to child birth and social expectations towards men. The opposite result found in this study may be related to the fact that the sample is composed of young women, mostly singles, that aren't assuming family responsibilities at this period of their lives.

The positive relationship between educational level and physical mobility found in this study is similar to the one found by Segers et al. (2008).

The fact of having or not children didn't present any statistically significant relation with any career attitude.

\section{Analysis of the influence of demographic and professional characteristics in career profiles}

Using the 8-group solution, an investigation regarding the impact of the demographic and professional characteristics in the profiles was conducted.

Table 6 indicates the statistically significant associations between career profiles and demographic/professional characteristics. The fact that certain demographics are represented in the Table doesn't indicate that it represents the biggest number of elements of this group, but it represents that this demographic segment presents a larger proportion of elements than the rest of the sample at a statistically significant level. The Oriented Traveler profile didn't present significant differences regarding demographics and therefore isn't represented in the Table. 
Table 6

Significant Associations between Demographics Characteristics and Career Profiles

\begin{tabular}{|c|c|c|c|c|c|c|c|}
\hline & Lost & $\begin{array}{c}\text { Stable } \\
\text { Protean }\end{array}$ & Seeker & $\begin{array}{l}\text { Organization } \\
\text { man/woman }\end{array}$ & $\begin{array}{c}\text { Solid } \\
\text { Citizen }\end{array}$ & Hired Gun & $\begin{array}{l}\text { Protean } \\
\text { Career } \\
\text { Architect }\end{array}$ \\
\hline Age & & $\begin{array}{l}18 \text { to } 22 \\
27 \text { to } 30\end{array}$ & & & & & 23 to 26 \\
\hline Gender & & & Women & & Men & & \\
\hline Education & Low & & & Low & & & High \\
\hline $\begin{array}{l}\text { Marital } \\
\text { Status }\end{array}$ & & & & & & & Single \\
\hline $\begin{array}{l}\text { Individual } \\
\text { Income }\end{array}$ & & & $\begin{array}{l}\text { Low/ } \\
\text { average }\end{array}$ & Low & & & High \\
\hline $\begin{array}{l}\text { Family } \\
\text { Income }\end{array}$ & & & & & $\begin{array}{l}\text { Up to } 2 \\
\text { minimum } \\
\text { wages }\end{array}$ & & High \\
\hline $\begin{array}{l}\text { State / City of } \\
\text { residence }\end{array}$ & & $\begin{array}{l}\text { São Paulo city } \\
\text { and South } \\
\text { region }\end{array}$ & & & & & \\
\hline $\begin{array}{l}\text { Current } \\
\text { working }\end{array}$ & & & & No & No & & Yes \\
\hline $\begin{array}{c}\text { Years of } \\
\text { professional } \\
\text { experience }\end{array}$ & & & & & & $\begin{array}{l}1 \text { to } 2 \text { and } \\
\text { more than } 5\end{array}$ & \\
\hline Job Title & & & $\begin{array}{l}\text { Analyst, } \\
\text { Assistant }\end{array}$ & & & & $\begin{array}{c}\text { Director, } \\
\text { Manager, } \\
\text { Coordinator, } \\
\text { Supervisor, } \\
\text { Consultant, } \\
\text { Trainee }\end{array}$ \\
\hline $\begin{array}{l}\text { Number of } \\
\text { employers }\end{array}$ & & & & Few & & & \\
\hline
\end{tabular}

Next is a brief description of the influence of demographic and professional characteristics in the career profiles.

Lost: the low educational level puts these individuals in a position of fewer employment opportunities. This can stimulate them to keep to the survival mode described by Briscoe and Hall (2006). The perspective of fewer opportunities may lead to low autonomy, limited values orientation and low mobility. The association between this profile and low educational level was also found by Segers et al. (2008) and theoretically described by Sullivan and Arthur (2006).

Stable Protean: this is the only cluster that presented a statistically significant difference regarding the location of residence, reaffirming that big cities, such as São Paulo, enable the Protean career development (Ribeiro et al., 2009).

Seeker: compared to the rest of the sample, this profile has a bigger proportion of women, individuals of low or average income and people holding positions such as analyst and assistant, that is, individuals that are going through their first career steps, which matches the theoretical description that the present study provided for this profile. 
Organization man/woman: the fact that a big number of people at this cluster aren't currently working may explain the low income of this group. This demographic features are compatible with the conceptual profile that describes that these career actors can easily work beyond psychological boundaries, but not physical boundaries, generating fewer moves and therefore reemployment difficulties. Vansteenkiste, Verbruggen, and Sels (2013) attribute this difficulty to their diverse set of interests and consequent low focus in the search. In other words, they are active in the search for new jobs, due to their psychological mobility, but they receive less job offers, due to their lack of focus. The low educational level can also harm reemployment and put them in the position of adapting themselves to third-party interests instead of their own needs and values.

Solid Citizen: has a bigger proportion of men, people with individual income up to two minimum wages and unemployed people. Again, the low physical mobility may harm their reemployment ability (Vansteenkiste, Verbruggen, \& Sels, 2013).

Hired Gun: has a bigger proportion of individuals with more than 5 years of professional experience. This result is similar to the ones found by Segers et al. (2008).

Protean Career Architect: this is the cluster that presents the largest number of variables that distinguishes itself from the others. It has a greater proportion of single and high educational level individuals. They have high individual and family income and are employed. They hold leadership roles and trainee positions at a higher frequency than the other clusters. Segers et al. (2008) study also identified a higher presence of people holding managerial positions in this group.

Having children or not didn't present any statistically significant association with any career profile investigated.

\section{Final Considerations}

This study identified the career profiles among Generation $\mathrm{Y}$ and proved that demographic and professional variables influence individual career attitudes.

The usage of the career attitudes scale followed by the classification into career profiles was innovative. No studies were found with similar joint analysis, since the career profiles were only conceptually developed by Briscoe and Hall (2006).

Five from the eight groups described by Briscoe and Hall (2006) were found: Lost, Organization man/woman, Solid Citizen, Hired Gun and Protean Career Architect. Three new groups were found and classified as Stable Protean (high self-direction and values driven, low psychological mobility and neutral physical mobility), Oriented Traveler (low self-direction, high values-driven, low psychological mobility and high physical mobility) and Seeker (low self-direction, neutral values-driven, high psychological and physical mobility).

The predominant profile is the Protean Career Architect that composes 23\% of the sample. This is the profile with a high presence of all new careers attitudes, confirming Generations theory, that enounces that the socialization of young individuals in a modern, competitive, globalized and dynamic workplace stimulates them to adapt their career profiles to this reality (Edmunds \& Turner, 2005; R. C. da Silva et al., 2012; Tapscott, 2010) and also confirms career theories that describes the strong influence of this modern work environment in individuals' career attitudes (Arthur, 1994; Briscoe et al., 2006; Briscoe et al., 2012; Hall, 2002).

The Protean Career Architect profile predominance indicates that a large part of the young professionals look for autonomy, flexibility, continuous learning, openness to work beyond boundaries and freedom to perform physical moves. 
The fact that Brazil went through several economic crises until the end of the nineties made it a country more propitious to present bigger differences between the career profiles of different Generations (Briscoe et al., 2012). The larger presence of Protean Career Architects between the young people researched may have been influenced by the socio-economic context of the country. Amaral (2004) describes how unemployment situations and financial crises lived by parents affect their children's behaviors at work, making them less loyal to the organization and putting job satisfaction as a priority for this group.

The profile with a smaller representation is the Lost, at only $4 \%$ of the sample. This profile presents low presence of the career attitudes measured, making them part of the traditional career profile (Arthur, 1994). The individuals under this profile presented a lower educational level than the rest of the sample. Considering that the sample has a higher proportion of highly educated individuals than the national census, this traditional career profile can be even more prominent at national level than found at this study.

The variety of profiles found could also explain the contradictory results found in national studies regarding Generations and Careers (R. C. da Silva et al., 2012; Sá et al., 2014; Tieppo et al., 2011; Veloso et al., 2012), confirming that inside a Generational group there can be different ways to perceive and manage the career and also providing evidence that social variables are important to understanding these differences.

Checking the association between demographics and career attitudes, it is possible to conclude that new careers are associated with high educational levels and high income, especially the Boundaryless career.

Observing the sample distribution, it is clear that new careers are a reality to young Brazilian professionals. Nevertheless, there is a smaller portion of people with low career attitudes in several dimensions, indicating that it is just a movement and can't be considered as a reality for all individuals researched. There are still people that expect to be directed and supported by the organizations that they work for (Clarke, 2013; Rodrigues \& Guest, 2010; Sá et al., 2014) or people that don't have the conditions to manage their own careers, because of educational and financial limitations or exclusion problems (Inkson, 2006). This result also indicates that there are several configurations of Generation $\mathrm{Y}$ in Brazil due to the large socioeconomic inequality existing in the country (Rocha-de-Oliveira et al., 2012).

This study reinforces that Generations studies should consider social and educational variables to engage in a deeper analysis of the Brazilian specificities and to follow the full concept offered by Mannheim and Yncera (1993). Unfortunately, the country lacks sociological studies on the subject that could better sustain the development of theory in other fields, such as business administration and career management.

The first research limitation is related to the sample used in this study, which is non-probabilistic and intentional. The results presented can't be generalized, but the current study concentrated an expressive number of respondents that allowed for statistical analysis and provides important evidences about the different characteristics of the career attitudes and profiles in Brazil and also about the demographic characteristics of the actor of each career profile.

When only one Generation is chosen to be the focus of the study, another research limitation is created. It wasn't possible to compare the career profiles of different Generations. The study of only one Generation is suggested by Parry and Urwin (2011) as a solution to deepen the knowledge on the subject and avoid methodological errors of comparing Generations without excluding age and period effects. The comparative approach can be used in future studies on this subject.

This study suggests to organizations that building specific management models and practices for the Generation Y may present a low return over the investment, because inside the same Generation it is possible to observe different career profiles. Instead of implementing practices specifically for 
Generation Y, organizations should focus their efforts on implementing flexible work practices that can attend the needs and interests of different audiences and different career profiles.

Generation theory and the career profiles make an invitation for managers and young professionals to engage in dialogue, building an exchange of ideas, perceptions and expectations regarding work and career, considering that there are several possibilities. This research offered one more step to build a conceptual background, based on empirical evidence, of both theories in Brazil, sustaining the individual career development and the organizational growth, based on the synergy of interests and intentions.

\section{Note}

\footnotetext{
${ }^{1}$ Data collection for this research happened in 2012 and this article is being published in 2017. This time frame doesn't diminish the validity and importance of these findings, since, according to the authors that developed the original scale, the career profile of an individual isn't expected to change significantly in the short to medium-term and the results collected still reflect the career profiles of the Generation Y researched.
}

\section{References}

Amaral, S. E. do (2004). Virando gente grande: Como orientar os jovens em início de carreira. São Paulo: Gente.

Arthur, M. B. (1994). The boundaryless career: A new perspective for organizational inquiry. Journal of Organizational Behavior, 15(4), 295-306. https://doi.org/10.1002/job.4030150402

Arthur, M. B. (2014). The boundaryless career at 20: Where do we stand, and where can we go? Career Development International, 19(6), 627-640. https://doi.org/10.1108/cdi-05-2014-0068

Arthur, M. B., Inkson, K., \& Pringle, J. K. (1999). The new careers: Individual action and economic change. London: Sage Publications.

Arthur, M. B., \& Rousseau, D. M. (1996). The boundaryless career: A new employment principle for a new organizational era. New York: Oxford University Press.

Associação Brasileira de Empresas de Pesquisa. (2012). Critério de classificação econômica Brasil. Retrieved June 2, 2012, from http://www.abep.org/criterio-brasil

Baruch, Y., Szucs, N., \& Gunz, H. (2014). Career studies in search of theory: The rise and rise of concepts. Career Development International, 20(1), 3-20. https://doi.org/10.1108/cdi-11-20130137

Benson, J., \& Brown, M. (2011). Generations at work: Are there differences and do they matter? The International Journal of Human Resource Management, 22(9), 1843-1865. https://doi.org/10.1080/09585192.2011.573966

Briscoe, J. P., \& Hall, D. T. (2006). The interplay of boundaryless and protean careers: Combinations and implications. Journal of Vocational Behaviour, 69(1), 4-18. https://doi.org/10.1016/j.jvb.2005.09.002

Briscoe, J. P., Hall, D. T., \& DeMuth, R. L. F. (2006). Protean and boundaryless careers: An empirical exploration. Journal of Vocational Behaviour, 69(1), 30-47. https://doi.org/10.1016/j.jvb.2005.09.003 
Briscoe, J. P., Hall, D. T., \& Mayrhofer, W. (2012). Careers around the world: Individual and contextual perspectives. Nova York: Routledge.

Cavazotte, F. de S. C. N., Lemos, A. H. da C., \& Viana, M. D. de A. (2010, setembro). Relações de trabalho contemporâneas e as novas gerações produtivas: Renovadas ou antigos ideais? Anais do Encontro Nacional da Associação Nacional de Pós-Graduação e Pesquisa em Administração, Rio de Janeiro, RJ, Brasil, 34.

Clarke, M. (2013). The organizational career: Not dead but in need of redefinition. The International Journal of Human Resource Management, 24(4), 684-703. https://doi.org/10.1080/09585192.2012.697475

Cordeiro, H. T. D., \& Albuquerque, L. G. de (2016). Validação da escala de atitudes de carreira sem fronteiras e carreira proteana no Brasil. Revista de Carreiras e Pessoas, 6(2), 118-137. https://doi.org/10.20503/recape.v6i2.29409

Dencker, J. C., Joshi, A., \& Martocchio, J. J. (2007). Employee benefits as context for intergenerational conflict. Human Resource Management Review, 17(2), 208-220. https://doi.org/10.1016/j.hrmr.2007.04.002

Departamento Intersindical de Estatística e Estudos Socioeconômicos. (2011). Rotatividade e flexibilidade no mercado de trabalho. Retrieved May 13, 2012, from https://www.dieese.org.br/livro/2011/livroRotatividade11.pdf

Dutra, J. S. (Org.). (2010). Gestão de carreiras na empresa contemporânea. São Paulo: Atlas.

Edmunds, J., \& Turner, B. S. (2005). Global generations: Social change in the twentieth century. The British Journal of Sociology, 56(4), 559-577. https://doi.org/10.1111/j.1468-4446.2005.00083.x

Gomes, D. F. N., Trevisan, L. N., Veloso, E. F. R., \& Silva, R. C. (2013). Contribuição das âncoras de carreira para entender diferenças e similaridades de gênero e profissão na geração Y. Revista de Ciências Humanas, 47(1), 152-171. https://doi.org/10.5007/2178-4582.2013v47n1p152

Hair, J. F., Black, W. C., Babin, B. J., Anderson, R. E., \& Tatham, R. L. (2009). Análise multivariada de dados (6a ed.). Porto Alegre: Bookman.

Hall, D. T. (2002). Careers in and out of organizations. London: Sage.

Inkson, K. (2006). Protean and boundaryless careers as metaphors. Journal of Vocational Behavior, 69(1), 48-63. https://doi.org/10.1016/j.jvb.2005.09.004

Instituto Brasileiro de Geografia e Estatística. (n.d.). Sinopse dos resultados do censo 2010. Retrieved June 2, 2012, from http://www.censo2010.ibge.gov.br/sinopse/webservice

Lyons, S. T., Schweitzer, L., \& Ng, E. S. W. (2015). How have careers changed? An investigation of changing career patterns across four generations. Journal of Managerial Psychology, 30(1), 8-21. https://doi.org/10.1108/jmp-07-2014-0210

Mannheim, K., \& Yncera, I. S. de la (1993). El problema de las generaciones. REIS: Revista Española de Investigaciones Sociológicas, (62), 193-242. https://doi.org/10.2307/40183643

Nogueira, A. S., Lemos, A. H. da C., \& Cavazotte, F. de S. C. N. (2011, setembro). Impacto das diferenças geracionais no comprometimento dos oficiais intendentes com a organização comando da aeronáutica. Anais do Encontro Nacional da Associação Nacional de Pós-Graduação e Pesquisa em Administração, Rio de Janeiro, RJ, Brasil, 35. 
Parry, E., \& Urwin, P. (2011). Generational differences in work values: A review of theory and evidence. International Journal of Management Reviews, 13(1), 79-96. https://doi.org/10.1111/j.14682370.2010.00285.x

Rocha-de-Oliveira, S., Piccinini, V. C., \& Bitencourt, B. M. (2012). Juventudes, gerações e trabalho: É possível falar em geração Y no Brasil? Organizações \& Sociedade, 19(62), 551-558. https://doi.org/10.1590/s1984-92302012000300010

Rodrigues, R. A., \& Guest, D. (2010). Have careers become boundaryless? Human Relations, 63(8), 1157-1175. https://doi.org/10.1177/0018726709354344

Ribeiro, R., Trevisan, L. N., \& Guedes, R. M. (2009). Carreiras de profissionais de marketing com atuação em São Paulo: Uma avaliação da atitude proteana e das condições do ambiente para o desenvolvimento de uma carreira moderna. Anais do Encontro Nacional da Associação Nacional de Pós-Graduação e Pesquisa em Administração, São Paulo, SP, Brasil, 33.

Sá, P. F. de, Lemos, A. H. da C., \& Cavazotte, F. S. C. N. (2014). Expectativas de carreira na contemporaneidade: O que querem os jovens profissionais? Revista ADM.MADE, 18(2), 8-27. Retrieved from http://revistaadmmade.estacio.br/index.php/admmade/article/viewFile/879/518

Scalabrin, A. C. (2008). Carreiras sem fronteiras e trajetórias descontínuas: Um estudo descritivo sobre decisões de opt-out (Dissertação de mestrado). Faculdade de Economia Administração e Contabilidade, Universidade de São Paulo, São Paulo, SP, Brasil. Retrieved from http://www.teses.usp.br/teses/disponiveis/12/12139/tde-03092008-110945/

Segers, J., Inceoglu, I., Vloeberghs, D., Bartram, D., \& Henderickx, E. (2008). Protean and boundaryless careers: A study on potential motivators. Journal of Vocational Behavior, 73(2), 212-230. https://doi.org/10.1016/j.jvb.2008.05.001

Silva, J. de A. (2009). Estudo comparativo dos modelos de carreira proteana e carreira sem fronteiras por meio de escalas de atitudes (Dissertação de mestrado). Universidade Federal de Uberlândia, Uberlândia, MG, Brasil. Retrieved from https://repositorio.ufu.br/handle/123456789/11926

Silva, R. C. da, Dias, C. A. de F., Silva, M. T. G., Krakauer, P. V. de C., \& Marinho, B. de L. (2012). Carreiras: novas ou tradicionais? Um estudo com profissionais brasileiros. Revista de Carreiras e Pessoas, 2(1), 19-39. Retrieved from https://revistas.pucsp.br/index.php/ReCaPe/article/view/9337/7008

Silva, R. C. da, Dutra, J. S., \& Veloso, E. (2013). A gestão das gerações em uma empresa que nasceu "Y" nos anos 1960: Os papéis funcionais em sobreposição à idade. Revista Administração em Diálogo, 15(3), 133-157. https://doi.org/10.20946/rad.v15i3.23146

Silva, R. C. da, Dutra, J. S., \& Veloso, E. (2014). O conhecimento e a experiência em sobreposição à idade: A gestão das gerações de uma organização industrial. Gestão Contemporânea, (15), 254277. Retrieved from http://seer4.fapa.com.br/index.php/arquivo/article/view/356/158

Smola, K. W., \& Sutton, C. D. (2002). Generational differences: Revisiting generational work values for the new millennium. Journal of Organizational Behavior, 23(4), 363-382. https://doi.org/10.1002/job.147

Sullivan, S. E., \& Arthur, M. B. (2006). The evolution of the boundaryless career concept: Examining physical and psychological mobility. Journal of Vocational Behaviour, 69(1), 19-29. https://doi.org/10.1016/j.jvb.2005.09.001

Tapscott, D. (2010). A hora da geração digital: Como os jovens que cresceram usando a internet estão mudando tudo, das empresas aos governos. Rio de Janeiro: Agir Negócios. 
Tieppo, C. E., Gomes, D. F. N., Sala, O. T. M, \& Trevisan, L. N. (2011). Seriam as âncoras de carreira aderentes às carreiras inteligentes? Um estudo comparativo entre alunos formandos do curso de administração de empresas e turismo. Revista Gestão Organizacional, 4(2), 273-293. Retrieved from https://bell.unochapeco.edu.br/revistas/index.php/rgo/article/view/893/530

Twenge, J. M., \& Campbell, S. M. (2008). Generational differences in psychological traits and their impact on the workplace. Journal of Managerial Psychology, 23(8), 862-877. https://doi.org/10.1108/02683940810904367

Twenge, J. M., Campbell, S. M., Hoffman, B. J., \& Lance, C. E. (2010). Generational differences in work values: Leisure and extrinsic values increasing, social and intrinsic values decreasing. Journal of Management, 36(5), 1117-1142. https://doi.org/10.1177/0149206309352246

Vale, J. C. F. do, Lima, T. C. B. de, \& Queiroz, G. C. (2011, setembro). O comprometimento organizacional entre grupos geracionais em uma instituição federal de ensino superior. Anais do Encontro Nacional da Associação Nacional de Pós-Graduação e Pesquisa em Administração, Rio de Janeiro, RJ, Brasil, 35.

Vansteenkiste, S., Verbruggen, M., \& Sels, L. (2013). Being unemployed in the boundaryless era: Does psychological mobility pay off? Journal of Vocational Behavior, 82(2), 135-143. https://doi.org/10.1016/j.jvb.2012.11.007

Vasconcelos, K. C. de A., Merhi, D. Q., Lopes, V. M. G., \& Silva, A. R. L. da. (2009, novembro). A geração Y e suas âncoras de carreira. Anais do Encontro de Gestão de Pessoas e Relações de Trabalho, João Pessoa, PB, Brasil, 2.

Veloso, E. F. R., Dutra, J. S., \& Nakata, L. E. (2008, setembro). Percepção sobre carreiras inteligentes: Diferenças entre as gerações Y, X e baby boomers. Anais do Encontro Nacional da Associação Nacional de Pós-Graduação e Pesquisa em Administração, Rio de Janeiro, RJ, Brasil, 32.

Veloso, E. F. R., Silva, R. C. da, \& Dutra, J. S. (2012). Diferentes gerações e percepções sobre carreiras inteligentes e crescimento profissional nas organizações. Revista Brasileira de Orientação Profissional, 13(2), 197-207. $\quad$ Retrieved from http://pepsic.bvsalud.org/scielo.php?script=sci_arttext\&pid=S1679-33902012000200007

\section{Authors' Profiles}

Helena Talita Dante Cordeiro

Av. Prof. Luciano Gualberto, 908, 05508-010, São Paulo, SP, Brazil. E-mail address: htalitacordeiro@gmail.com. http://orcid.org/0000-0003-4367-9167

Lindolfo Galvão de Albuquerque

Av. Prof. Luciano Gualberto, 908, 05508-010, São Paulo, SP, Brazil. E-mail address: Igdalbuq@usp.br 